\title{
Orthographic Knowledge of Hangul Syllable in Alzheimer's Disease
}

\author{
Ji Hye Yoon ${ }^{\mathrm{a}}$, HyangHee Kim ${ }^{\mathrm{b}}$, Duk L. Na ${ }^{\mathrm{c}}$, Mee Kyung Suh ${ }^{\mathrm{d}}$ \\ ${ }^{a}$ Department of Speech Pathology and Audiology, Audiology and Speech Pathology Research Institute, College of Natural Sciences, Hallym \\ University, Chuncheon, Korea \\ ${ }^{b}$ Department and Research Institute of Rehabilitation Medicine, Yonsei University College of Medicine, Seoul, Korea \\ 'Department of Neurology, Samsung Medical Center, Sungkyunkwan University School of Medicine, Seoul, Korea \\ ${ }^{d}$ Department of Neurology, Samsung Medical Center, Seoul, Korea
}

Correspondence: HyangHee Kim, PhD Graduate Program in Speech and Language Pathology, Yonsei University College of Medicine, 50 Yonsei-ro, Seodaemun-gu, Seoul 120-752, Korea Tel: +82-2-2228-3900

Fax: +82-2-2227-7984

E-mail: h.kim@yonsei.ac.kr

Received: January 5, 2013

Revised: January 29, 2013

Accepted: February 5, 2013

This manuscript is partly based on the doctoral dissertation of the first author.

This research was supported by Hallym University Research fund, 2012 (HRF-201209-022).
Objectives: Alzheimer's disease (AD) can cause visuoconstructional and linguistic dysfunction due to bilateral involvement of the tempoparietal-frontal hemispheric areas. At the later stages of disease, the patients often manifest written language impairment. Generalized orthographic knowledge/representation, that is, knowledge of symbol and letter patterns within and across words, is important for written language. The aim of this study was to delineate the basic knowledge of the graphemic or syllabic shapes in Hangul as well as Hangul writing ability of those with AD. We hypothesized that the orthographic representation of Hangul syllable might withstand the impact of $A D$, because the basic knowledge of a letter shape of Hangul might be preserved in this clinical population. Methods: Seventy-five $A D$ patients were included in this study. The patient group was divided into four subgroups according to the clinical dementia rating (CDR): 16 were very mild cases (CDR0.5); 37, mild (CDR1); 19, moderate (CDR2); and 3, severe (CDR3). We administered dictation and representation tasks of Hangul syllables and compared the performances among groups. Results: In the writing-to-dictation and representation tasks, the number of correct responses significantly differed according to CDR $(p<.001)$. Interestingly, the patients at a later stage of the disease received scores of below $10 \%$ on the Hangul writing to dictation task, and $41.5 \%$ on the Hangul representation tasks. Conclusion: This finding supports the hypothesis that orthographic knowledge/representation of Hangul grapheme/syllable may partly withstand the impact of AD.

Keywords: Hangul, Orthographic knowledge, Alzheimer's disease
Normal spelling and writing can be performed with an ensemble of intact skills including visuospatial orientation, construction, and linguistic capacities. Generalized orthographic knowledge/ representation, that is, knowledge of symbol and letter patterns within and across words, is also important for written language (Kaefer, 2009).

Alzheimer's disease (AD) is a disease that can result in both visuoconstructional and linguistic dysfunction during the course of the disease, due to bilateral involvement of the tempoparietal-fron- tal hemispheric areas. AD patients usually manifest writing impairment. Previous studies on Korean AD patients showed that writing impairments are closely related to functional decline in both the right and left hemispheres (Yoon et al., 2011, 2012).

The Korean alphabet, Hangul (or Hangeul), is composed of uniquely shaped letters. In terms of syllabic forms, the English alphabet is always arranged in a linear string fashion from left to right. What makes the Hangul syllable so unique is that it can be arranged vertically, horizontally, and with a combination of the 
two. Each consonant(s) and vowel(s) needs to be arranged in a square form, which represents one syllable. In addition, in the physical forms of graphemes, the ten basic vowels are derived from three basic geometric shapes, which represent the three fundamental elements in Eastern cosmology (i.e., heaven, earth, and humanity). The consonants are modeled after pictorial vocal representations. For example, ' $\neg / g$ /' depicts the root of the tongue blocking the throat.

Research on the knowledge of the graphemic or syllabic shapes in Hangul as well as the characteristics of Hangul writing would provide additional information for non-alphabetic written language systems. To date, the hypothesis that Hangul writing contains not only linguistic but also visuospatial characteristics, has been confirmed in Korean stroke (Kim, Na, \& Park, 2007) and AD patients (Yoon et al., 2011, 2012). However, studies on the characteristics of orthographic representation in Hangul are very limited. With respect to the visuospatial representation of syllabic shape of Hangul writing, Kim, Na, \& Park (2007) proposed that the representation of Hangul syllabic shape remained intact despite the cerebrovascular disease. In a similar token, studies on English and Italian-speaking adults showed rigid positions of vowel-consonant status in a word (Glasspool \& Houghton, 2005; Miceli, Capasso, Benvegnu, \& Caramazza, 2004).

Orthographic representation is a basic element of reading and writing processes. Lavine (1977) and Bialystok (1995) suggested that young pre-school children possess some orthographic knowledge. When 5-year-old children were presented with different types of printed stimuli, they were able to label printed words and pseudowords as writing. The aim of this study was to delineate the basic knowledge of the graphemic or syllabic shapes in Hangul as well as Hangul writing ability of those with AD. We hypothesized that the orthographic representation of Hangul syllable might withstand the impact of the $\mathrm{AD}$ because the basic knowledge of a letter shape of Hangul might be preserved in the clinical population.

\section{METHODS}

\section{Subjects}

Seventy-five AD patients in a previous study (Yoon et al., 2012) were also included in this study. All patients fulfilled the criteria, proposed by the National Institute of Neurological and Communicative Disorders and Stroke and the Alzheimer's Disease and Related Disorders Association (NINCDS-ADRDA), for having probable AD (McKhann et al., 1984). The exclusion criteria were as follows: 1) with less than "6 years of education", for they might have had difficulty writing Hangul in the premorbid state; 2) who showed abnormal findings on laboratory tests (i.e., a complete blood count, blood chemistry, vitamin $\mathrm{B}_{12}$ /folate, syphilis serology, thyroid-function tests); 3) showing territorial cerebral infarctions, brain tumors, and other structural lesions on magnetic resonance image; 4) with mild bradykinesia and rigidity that can influence writing ability; and 5) who refused to complete the Hangul writing and representation tests. The patient group was divided into four subgroups according to the clinical dementia rating (CDR): 16 were very mild cases (CDR0.5); 37, mild (CDR1) 19, moderate (CDR2); and 3, severe (CDR3). Table 1 presents demogrpahic variables according to the disease severity.

\section{Materials}

Hangul writing to dictation task

Performance on a Hangul writing to dictation task was conducted to identify the writing ability of the patients. The writing

Table 1. Demographic variables according to the disease severity

\begin{tabular}{|c|c|c|c|c|c|}
\hline & Total AD $(n=75)$ & CDR0.5 $(n=16)$ & CDR1 $(n=37)$ & $\operatorname{CDR2}(n=19)$ & $\operatorname{CDR} 3(n=3)$ \\
\hline Age (yr) & $73.1 \pm 9.5$ & $71.1 \pm 11.3$ & $73.5 \pm 8.6$ & $74.3 \pm 9.5$ & $68.7 \pm 11.4$ \\
\hline Sex, Female & $48(64.0)$ & $12(75.0)$ & $28(75.6)$ & $13(68.4)$ & $2(66.7)$ \\
\hline Education (yr) & $11.1 \pm 3.7$ & $11.4 \pm 4.1$ & $10.8 \pm 3.9$ & $11.1 \pm 3.1$ & $12.3 \pm 3.5$ \\
\hline MMSE & $17.5 \pm 5.8$ & $21.6 \pm 3.7$ & $18.2 \pm 4.3$ & $13.8 \pm 6.6^{*, \dagger}$ & $8.3 \pm 4.0^{*,+}$ \\
\hline
\end{tabular}

Values are presented as mean \pm SD or number (\%).

$\mathrm{AD}=$ Alzheimer's disease; MMSE=Mini-Mental State Examination; CDR=Clinical Dementia Rating.

${ }^{*} p<.05$ between CDR0.5 and CDR2, and between CDR0.5 and CDR3.

${ }^{\dagger} p<.05$ between CDR1 and CDR2, and between CDR1 and CDR3. 
task consisted of 60 single syllable characters. The selection of these particular characters as stimuli was based on configuration, frequency, and imageability. In terms of configuration, characters with four graphemes or less were selected to make the task less complicated. In terms of vocabulary frequency, words were selected from the frequently used words in the Learner's Dictionary of Korean (Seo, 2006). All words were concrete, to ensure high imageability. The stimuli are provided in the Appendices 1-3.

\section{Hangul representation task}

The aim of the orthographic representation task of Hangul was to assess the knowledge of the shape of a real Hangul grapheme and syllable. In this scenario, we created the pseudo-shaped graphemes and syllables as distracters which were not included in the Korean syllable inventory. This task was divided into two subcategories: the first subtask included 10 yes-no questions and the second included 10 four-choice test items. Real and pseudo-shaped graphemes and syllables belonged to the stimuli. The stimuli are provided in the Appendix.

\section{Language test}

All patients completed the Korean version of Western Aphasia Battery (WAB; Kim \& Na, 2004). The oral language subtests such as spontaneous speech, auditory comprehension, repetition, and naming are used to calculate the aphasia quotient (AQ). When the reading and writing scores are added, the language quotient (LQ) is obtained. The patients with AD exhibited a mean AQ of 82.1 and a LQ of 76.5 (maximum score $=100$ ). Table 2 shows the results of the language test according to the dementia disease severity.

\section{Procedure}

For the Hangul writing to dictation task, we requested the subjects to write on an A4-sized sheet of paper. Each Hangul stimulus was verbally presented to the patient with a word cue; for example, "Please write the syllable '가' (/ka/) of '가위' (/ka-wi/)." The subject was asked to verbally repeat the target stimulus before writing it to ensure that the stimuli were correctly understood.

The Hangul representation task did not require the written production of the syllable or the verbal description. As mentioned earlier, this task was divided into two subcategories. The first subtask was a form of yes-no questionnaire. Here, the subjects were shown one stimulus printed on a sheet. The instruction was "Try to judge if the shapes of the written Hangul syllables are correct or not." The second subtask consisted of multiple choice test items. The general principle of this subtask involved pointing to the correctly shaped syllable among four multiple-choice items. The instruction was "Point the correctly shaped Hangul syllable." The subjects first performed a practice item ('가').

\section{Analysis}

Hangul writing to dictation task

The number of the correctly produced Hangul syllables was counted. We assigned a score of " 1 " if the patient showed correct responses of all grapheme in a syllable, and a score of " 0 " for an incorrect or no response. The maximum score was 60 and the minimum, 0 .

Table 2. The results of the language test according to the dementia disease severity

\begin{tabular}{|c|c|c|c|c|}
\hline & $\operatorname{CDR0.5}(n=16)$ & $\operatorname{CDR} 1(n=37)$ & $\operatorname{CDR2}(n=19)$ & $\operatorname{CDR3}(n=3)$ \\
\hline Spontaneous speech & $17.9 \pm 1.5$ & $17.3 \pm 1.5$ & $15.9 \pm 2.7^{*}$ & $13.0 \pm 2.8^{*, \dagger}$ \\
\hline Auditory comprehension & $9.3 \pm 0.3$ & $8.9 \pm 1.2$ & $7.8 \pm 1.7^{*, t}$ & $6.2 \pm 2.8^{*, \dagger}$ \\
\hline Repetition & $9.1 \pm 0.6$ & $8.4 \pm 1.5$ & $6.6 \pm 2.6^{*, t}$ & $5.8 \pm 3.4^{*}$ \\
\hline Naming & $8.6 \pm 0.6$ & $7.9 \pm 1.4$ & $5.7 \pm 2.4^{*, t}$ & $4.7 \pm 3.1^{*, \dagger}$ \\
\hline Reading & $8.1 \pm 1.3$ & $7.4 \pm 2.4$ & $4.9 \pm 2.8^{*, t}$ & $3.0 \pm 3.5^{*, \dagger}$ \\
\hline Writing & $8.0 \pm 2.0$ & $7.3 \pm 2.1$ & $4.6 \pm 3.3^{*, t}$ & $2.6 \pm 3.6^{*, \dagger}$ \\
\hline Aphasia quotient & $90.2 \pm 4.5$ & $85.2 \pm 9.8$ & $72.6 \pm 17.4^{*, \dagger}$ & $59.7 \pm 22.5^{*, \dagger}$ \\
\hline Language quotient & $87.0 \pm 8.1$ & $81.1 \pm 13.8$ & $63.5 \pm 21.3^{*, \dagger}$ & $47.7 \pm 28.1^{*, \dagger}$ \\
\hline
\end{tabular}

Values are presented as mean \pm SD.

CDR: Clinical Dementia Rating.

${ }^{*} p<.05$ between CDR0.5 and CDR2, and between CDR0.5 and CDR3.

${ }^{\dagger} p<.05$ between CDR1 and CDR2, and between CDR1 and CDR3. 
Hangul representation task

We assigned a score of " 1 " and "0" for correct and incorrect responses, respectively. The maximum score was 20 .

\section{Statistics}

One-way analysis of variance and post hoc Bonferroni correction were conducted to identify differences according to disease severity within the $\mathrm{AD}$ group regarding the number of correct responses.

\section{RESULTS}

In the writing to dictation task, the number of correct responses significantly differed according to CDR $(p<.001)$ (Table 3). By comparing the mean number of correct responses among the patient groups, there were significant differences between CDR0.5 and CDR2, CDR0.5 and CDR3, CDR1, and CDR2, and between CDR1 and CDR3. No differences were observed between CDR0.5 and CDR1, and between CDR2 and CDR3 $(p<.05)$.

In the representation task, the number of correct responses significantly differed according to CDR $(p<.001)$ (Table 3$)$. There were significant differences of the correct responses between CDR0.5 and CDR2, CDR0.5 and CDR3, and between CDR1 and CDR3 $(p<.05)$.

In the early stage of disease (CDR0.5 and CDR1), the patients showed correct responses above $75 \%$ in both writing to dictation and Hangul representation tasks. The CDR2 group showed correct responses below 50\% in Hangul writing to dictation task, but the Hangul representation was preserved with $60 \%$ of accuracy in the group. The CDR3 patients showed correct responses below $10 \%$ in Hangul writing to dictation task, and could manifest $41.5 \%$ of accuracy in Hangul representations.

\section{CONCLUSION}

We hypothesized that the orthogrpahic representation of Hangul syllable might withstand the impact of AD because the knowledge of a letter shape of Hangul might be preserved in the clinical popoulation. The primary finding from this study was that the later stages of $\mathrm{AD}$ affects the orthogrpahic representation of Hangul less than Hangul writing ability.

Typically, patients with severe stages of AD experienced more problems with linguistic and motoric components in writing, and showed more errors in writing to dictation (Forbes, Shanks, \& Venneri, 2004; Neils-Strunjas, Shuren, Roeltgen, \& Brown, 1998; Platel et al., 1993). In our group of late stages of $\mathrm{AD}$, the patients also showed more errors and the performance showed scores of below $10 \%$ in the Hangul writing to dictation task. Based on the sub-score of the reading test of WAB, these CDR3 patients could not read aloud or understand context well (the reading score $=3.0$ $\pm 3.5)$. However, they manifested $41.5 \%$ of accuracy in the Hangul representation tasks. On the other hand, for those in the early stage of $\mathrm{AD}$ (CDR1), the performance showed scores above $75 \%$ in both writing to dictation and the Hangul representation tasks. In this stage, the abilities to write and recognize the Hangul syllable are similar. In short, a higher discrepancy between the performance of writing and representation tasks was observed in CDR3.

The explanation for these phenomena is two-fold. Firstly, the representation task requires relatively less higher cognitive processes. In this task, the subjects only had to discern and point to the correctly shaped syllable in the form of a yes-no questionnaire and four multiple-choice items, respectively. It did not require written production of the syllable or verbal description. However, writing to dictation is a high-level, complex, cognitive process and requires a series of steps (e.g., neuropsychologic and motor functions) for its successful execution. Jauk, Benedek, \& Neubauer (2012)

Table 3. The mean number and percentage (\%) of correct responses of writing to dictation task and Hangul representation task

\begin{tabular}{lrrrrr}
\hline & $\operatorname{CDR0.5}(n=16)$ & $\operatorname{CDR} 1(n=37)$ & $\operatorname{CDR} 2(n=19)$ & $\operatorname{CDR3}(n=3)$ & Total AD $(n=75)$ \\
\hline Writing to dictation (maximum score $=60)$ & $49.1 \pm 10.2(81.6)$ & $46.1 \pm 15.2(76.6)$ & $29.0 \pm 20.5^{*, \dagger}(48.3)$ & $3.6 \pm 6.3^{*, \dagger}(6.0)$ & $41.4 \pm 18.3(69.0)$ \\
Representation (maximum score $=20)$ & $18.2 \pm 1.4(90.0)$ & $16.6 \pm 3.0(80.0)$ & $12.3 \pm 6.4^{*}(60.0)$ & $8.3 \pm 5.7^{*, \dagger}(41.5)$ & $15.5 \pm 4.7(77.5)$ \\
\hline
\end{tabular}

Values are presented as mean $\pm S D(\%)$.

CDR: Clinical Dementia Rating; $\mathrm{AD}=$ Alzheimer's disease

${ }^{*} p<.05$ between CDR0.5 and CDR2, and between CDR0.5 and CDR3.

${ }^{\dagger} p<.05$ between CDR1 and CDR2, and between CDR1 and CDR3. 
mentioned that divergent behavior involves the use of broad search of cognitive storage whereas convergent behavior involves a narrow search of the storage. In this point of view, the Hangul representation task as a convergent task is a straightforward method whereas the writing to dictation task may be a divergent task. Thus, our finding may be ascribed to the fact that the deficits in the divergent task worsen with progression of the disease.

Secondly, it can be assumed that the early acquired orthographic representation/knowledge of Hangul grapheme/syllable might be preserved in the later stage of $\mathrm{AD}$. The orthographic representation/knowledge is acquired in the very early stages of development (Frith, 1986; Kaefer, 2009). There was evidence that pre-reading children can show orthographic knowledge. Retrogenesis can be defined as the process by which degenerative mechanisms mirror the inverse sequences of the maturation process of normal development (Reisberg et al., 2002). Kim et al. (2011) observed that $\mathrm{AD}$ patients tend to first lose words learned more recently while maintaining those learned during earlier stages of development. From the aspect of retrogenesis (Kim et al, 2011; Reisberg et al., 2002), early acquired orthographic knowledge of Hangul grapheme/syllable might be at least partially, if not totally, remained in the minds of Korean $\mathrm{AD}$ patients even though they lack abilities to read and write. However, impairment of the basic knowledge of language, as writing ability is finally disrupted, might be also detected in the terminal stage of $\mathrm{AD}$.

This study is noteworthy because this is the first attempt to describe orthographic knowledge of Hangul in patients with AD. Limitations and suggestions of the study are as follows. With respect to sample size for the later stage of $\mathrm{AD}$ (i.e., CDR3), the number of subjects was not large enough to allow safe conclusions to be drawn, so future studies are needed to clarify the results. In the future, we would like to investigate whether the preservation of orthographic knowledge is restricted to Hangul, or whether it also affects other orthographic systems such as Chinese and English. In addition, investigation of the relationship between the representation for orthographic (i.e., grapheme or syllable) and non-orthographic systems (i.e., object) will provide additional information for the underlying mechanism of such representation in AD. Lastly, future studies are warranted to explore the specific brain regions related to the orthographic knowledge of Hangul.

\section{REFERENCES}

Bialystok, E. (1995). Making concepts of print symbolic: understanding how writing represents language. First Language, 15, 317-338.

Forbes, K. E., Shanks, M. F., \& Venneri, A. (2004). The evolution of dysgraphia in Alzheimer's disease. Brain Research Bulletin, 63, 19-24.

Frith, U. (1986). A developmental framework for developmental dyslexia. Annals of Dyslexia, 36, 69-81.

Glasspool, D. W., \& Houghton G. (2005). Serial order and consonant-vowel structure in a graphemic output buffer model. Brain and Language, 94, 304-330.

Jauk, E., Benedek, M., \& Neubauer, A. C. (2012). Tackling creativity at its roots: evidence for different patterns of EEG alpha activity related to convergent and divergent modes of task processing. International Journal of Psychophysiology, 84, 219-225.

Kaefer, T. (2009). Implicit, eclipsed, but functional: the development of orthographic knowledge in early readers (Doctoral dissertation). Duke University, Durham, NC.

Kim, H., \& Na, D. L. (2004). Normative data on the Korean version of the Western Aphasia Battery. Journal of Clinical and Experimental Neuropsychology, 26, 1011-1020.

Kim, H., Na, D. L., \& Park, E. S. (2007). Intransient vowel-consonant position in Korean dysgraphia: evidence of spatial-constructive representation. Behavioural Neurology, 18, 91-97.

Kim, H., Yoon, J. H., Lee, J. E., Baek, E. J., Sohn, Y. H., \& Na, D. L. (2011). Is confrontation naming performance in Alzheimer's disease the nominal linguistic retrogenesis of normal development? European Neurology, 66, 195-199.

Lavine, L. O. (1977). Differentiation of letterlike forms in prereading children. Developmental Psychology, 13, 89-94.

McKhann, G., Drachman, D., Folstein, M., Katzman, R., Price, D., \& Stadlan, E. M. (1984). Clinical diagnosis of Alzheimer's disease: report of the NINCDS-ADRDA Work Group under the auspices of Department of Health and Human Services Task Force on Alzheimer's Disease. Neurology, 34, 939-944.

Miceli, G., Capasso, R., Benvegnu, B., \& Caramazza, A. (2004). The categorical distinction of vowel and consonant representations: evidence from dysgraphia. Neurocase, 10, 109-121.

Neils-Strunjas, J., Shuren, J., Roeltgen, D., \& Brown, C. (1998). Perseverative writing errors in a patient with Alzheimer's disease. Brain and Language, 
Ji Hye Yoon, et al. • Orthographic Knowledge in Alzheimer's Disease

$63,303-320$.

Platel, H., Lambert, J., Eustache, F., Cadet, B., Dary, M., Viader, F., \& Lechevalier, B. (1993). Characteristics and evolution of writing impairment in Alzheimer's disease. Neuropsychologia, 31, 1147-1158.

Reisberg, B., Franssen, E. H., Souren, L. E. M., Auer, S. R., Akram, I., \& Kenowsky, S. (2002). Evidence and mechanisms of retrogenesis in Alzheimer's and other dementias: management and treatment import. American Journal of Alzheimers Disease and Other Dementias, 17, 202-212.
Seo, S. K. (2006). Learner's dictionary of Korean. Seoul, Korea: Shinwon Prime. Yoon, J. H., Suh, M. K., Jeong, Y., Ahn, H. J., Moon, S. Y., Chin, J., Seo, S. W., \& Na, D. L. (2011). Agraphia in Korean patients with early onset Alzheimer's disease. International Psychogeriatrics, 23, 1317-1326.

Yoon, J. H., Kim, H., Seo, S. W., Chin, J., Kim, J. H., Lee, K. H., Kim, Y. W., Park, E. S., Suh, M. K., \& Na, D. L. (2012). Dysgraphia in Korean patients with Alzheimer's disease as a manifestation of bilateral hemispheric dysfunction. Journal of the Neurological Sciences, 320, 72-78. 
Appendix 1. The stimuli of the Hangul writing to dictation task

\begin{tabular}{|c|c|c|c|c|c|c|c|c|c|c|}
\hline \multirow{2}{*}{$\begin{array}{l}\text { Category } \\
\text { Horizontal writing }\end{array}$} & \multicolumn{10}{|c|}{ Stimuli } \\
\hline & 뼈 & 싸 & 때 & 처 & 내 & 짜 & 새 & 커 & 혀 & 깨 \\
\hline & 애 & 꺼 & 야 & 배 & 펴 & 해 & 띠 & 매 & 태 & 떠 \\
\hline \multirow[t]{2}{*}{ Vertical writing } & 귤 & 순 & 춥 & 불 & 목 & 등 & 콩 & 쑥 & 똥 & 중 \\
\hline & 봄 & 풀 & 곰 & 논 & 육 & 홀 & 국 & 좁 & 북 & 금 \\
\hline \multirow[t]{2}{*}{ Mixed- orientation writing } & 왁 & 권 & 환 & 쉽 & 괜 & 월 & 뀡 & 된 & 광 & 휠 \\
\hline & 집 & 화 & 병 & 꾀 & 뭐 & 학 & 줘 & 놔 & 길 & 쇠 \\
\hline
\end{tabular}

Appendix 2. The stimuli of the Hangul representation task: yes-no questionnaire

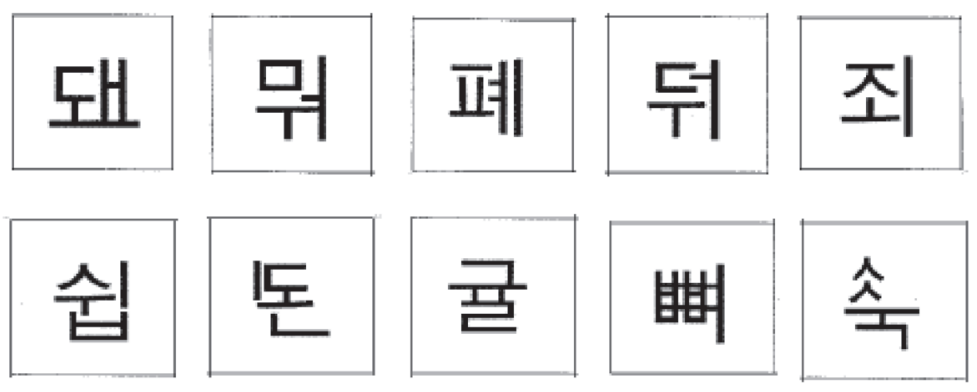

Appendix 3. The stimuli of the Hangul representation task: multiple choice test items

\begin{tabular}{|c|c|c|c|}
\hline 학 & 15 & 하 & 아 \\
\hline 찹돕 & 춭 & 출 & 音 \\
\hline 개 & 갑 & 가 & $\mathrm{CCH}$ \\
\hline 논 & 1노 & 노나 & 누나 \\
\hline 를 & 톰 & 뭉 & 등 \\
\hline 무서 & 무긔 & 무 & 무디 \\
\hline 호 & 市卜 & 호거 & 호 \\
\hline 리 & 기 & 고 & 工1 \\
\hline 픈 & 편여 & 픈거 & 픈1 \\
\hline 운 & 운서 & 으의 & 운기 \\
\hline
\end{tabular}




\section{국문초록}

\section{알츠하이머성 치매환자의 한글 철자 지식}

윤지혜 ${ }^{1} \cdot$ 김향희 $^{2} \cdot$ 나덕렬 $^{3} \cdot$ 서미경 4

'한림대학교 언어청각학부, ${ }^{2}$ 연세대학교 대학원 언어병리학협동과정, 의과대학 재활의학교실 및 재활의학연구소, ${ }^{3}$ 성균관의대 신경과학교실, 삼성서울병원 신경과, 4삼성서울병원 신경과

배경 및 목적: 올바른 쓰기 수행에는 발달의 비교적 초기단계에 습득되는 기본적 철자 지식을 바탕으로 언어적 능력과 시공간 구성능 력이 필요하다. 알츠하이머성 치매는 좌, 우반구에 아밀로이드 단백질이 침착되고, 언어능력과 관련있는 측두엽과 시공간 구성능력과 관련있는 두정엽에 위축을 보인다. 알츠하이머성 치매환자의 쓰기수행에 대한 선행 연구를 통하여 언어적 오류와 더불어 시공간적 오 류가 확인되었다. 그러나 쓰기수행 연구에 비하여 한국 알츠하이머성 환자의 철자 지식 및 표상에 대한 능력에 대한 연구는 제한적이다. 따라서 본 연구에서는 한글 쓰기능력과 관련하여 한글 음절이나 글자에 대한 지식이 어떠한 관계가 있는지 알아보고자 하였다. 방법: 75명의 알츠하이머성 치매환자를 대상으로 한글 쓰기 및 한글표상능력 확인을 위한 판단과제를 시행하였다. 결과: 치매중증도가 심한 환자군에서 한글 받아쓰기 수행은 상당히 저하됨에도 불구하고 한글표상능력에서는 약 $41.5 \%$ 정도의 정반응률이 관찰되었다. 논의 및 결론: 발달초기에 습득되는 기본적인 한글 음절 및 글자에 대한 지식은 알츠하이머성 치매질환이 진행되면서 환자가 글을 읽고 쓸 수 없는 경우에도 여전히 부분적으로 보존됨을 확인하였다.

핵심어: 한글, 철자 지식, 표상, 알츠하이머병

본 연구는 제 1 저자의 박사학위 논문(2012) 일부를 요약한 것임.

이 논문은 2012년도 한림대학교 교비연구비(HRF-201209-022)에 의하여 연구되었음. 